\title{
PENDAMPINGAN MASYARAKAT MELALUI PROGRAM KEAKSARAAN DI DISTRIK WALELAGAMA, WAMENA KABUPATEN JAYAWIJAYA, PAPUA
}

\author{
Sepling Paling ${ }^{1)}$, Irsan Hengky Sulendorong ${ }^{2)}$, Brigita Oagay ${ }^{3)}$ \\ ${ }^{1}$ Program Studi Pendidikan Matematika, Sekolah Tinggi Keguruan dan Ilmu Pendidikan Kristen Wamena \\ ${ }^{2,3}$ Program Studi Pendidikan Bahasa Inggris, Sekolah Tinggi Keguruan dan Ilmu Pendidikan Kristen \\ Wamena \\ email: seplinpalin@gmail.com
}

\begin{abstract}
Abstrak
Salah satu provinsi yang memiliki angka buta aksara paling tinggi di Indonesia adalah Provinsi Papua yaitu sebanyak 28,75\% dari 70,26\% pada 11 Provinsi di Indonesia. Khusus di kabupaten Jayawijaya sebanyak $25.80 \%$ masyarakat yang masih buta aksara. Hal ini disebabkan karena kondisi geografis yang cukup luas, daerah yang sulit dijangkau, penyebaran penduduk asli Papua yang tidak merata pada daerah yang terisolir. Guna mengatasi tingginya angka buta aksara di Kabupaten Jayawijaya khususnya di Distrik Walelagama kampung Walelagama, maka Sekolah Tinggi Keguruan dan Ilmu Pendidikan Kristen Wamena selaku praktisi pendidikan yang bertanggung jawab terhadap mutu pendidikan di Pegunungan Tengah Papua, maka perlu melakukan program pendampingan keaksaraan bagi masyarakat. Program ini dilaksanakan selama 3 bulan bagi warga kampung Walelagama yang berusia 15 - 45 tahun baik yang tidak pernah sekolah maupun yang putus sekolah. Diharapkan melalui pendampingan ini, kemampuan baca dan tulis warga Walelagama menjadi lebih baik, sehingga dapat mempengaruhi pola hidup masyarakat yang ada di kampung Walelagama. Setelah dilakukan pendampingan keaksaraan terlihat perubahan pada kemampuan literasi warga belajar di kampung walelagama. Hal ini diukur dari tes awal dan tes akhir yang diberikan pada warga belajar sebelum pendampingan dan setelah pendampingan.
\end{abstract}

Kata Kunci: Keaksaraan, Buta Aksara, Walelagama, Jayawijaya, STKIP Kristen Wamena

\begin{abstract}
One of the provinces with the highest illiteracy rate in Indonesia is Papua Province, which is $28.75 \%$ of $70.26 \%$ in 11 Provinces in Indonesia. Especially in Jayawijaya district, $25.80 \%$ of the people are still illiterate. This is due to the extensive geographical conditions, difficult to reach areas, the spread of Papuans that are not evenly distributed in isolated areas. In order to overcome the high rate of illiteracy in Jayawijaya District, especially in the Walelagama District of Walelagama village, Wamena Christian Teacher Training and Education School as the education practitioner responsible for the quality of education in the Central Papua Mountains carried out literacy assistance programs for the Walelagama village community in Wamena in the District Jayawijaya, Papua. The program was held for 3 months for residents of Walelagama villages aged 15-45 years who had never attended school or dropped out of school. It is hoped that through this assistance, the reading and writing skills of Walelagama residents will be better, so that it can influence the lifestyle of the people in Walelagama village. After literacy assistance, there was a change in the literacy skills of the people studying in the Walelagama village. This was measured from the initial test and the final test given to the study residents before mentoring and after mentoring.
\end{abstract}

Keywords: Literacy, Illiteracy, Walelagama, Jayawijaya, Papua, STKIP Kristen Wamena 


\section{PENDAHULUAN}

Pendidikan merupakan salah satu media yag dapat meningkatkan taraf hidup manusia. Melalui pendidikan, seseorang dapat mengembangkan potensi diri dalam mengatasi berbagai hambatan dalam hidup bermasyarakat. Untuk itu, setiap orang di Indonesia berhak untuk memperoleh pendidikan seperti yang tercantum dalam Undang-Undang Dasar (UUD) Tahun 1945 Pasal 31 (Amandemen IV) ayat 1 yang menyatakan bahwa "tiap-tiap warga negara berhak mendapatkan pengajaran".

Berpedoman pada UUD di atas, maka pemerintah Indonesia kian giat meningkatkan sistem pendidikan di Indonesia melalui penganggaran $20 \%$ dari APBN yang ada. Meskipun demikian, tingginya angka buta aksara di Indonesia masih menjadi polemik yang tidak kunjung terselesaikan sampai saat ini.

Wartanto, Direktur Pembinaan Pendidikan Masyarakat Direktorat Jenderal Pendidikan Anak Usia Dini, Nonformal, dan Informal Kementerian Pendidikan mengatakan bahwa "angka rata-rata warga buta aksara di Provinsi Papua dan Papua Barat masih tergolong sangat tinggi. Bahkan di daerah tertentu, mencapai 80\%" (Harian Jaringan Kerja Rakyat Papua, 2015).

Fenomena pendidikan yang terjadi di daerah Pegunungan Tengah Papua masih tergolong sangat rendah. Hal ini dibuktikan dengan tingginya angka masyarakat di provinsi Papua yang belum bisa membaca, menulis dan berhitung dengan baik yaitu sekitar 28, 75\%. Khusus di daerah Kabupaten Jayawijaya terdapat 25,80 \% masyarakat yang berumur 15 tahun ke atas yang belum bisa membaca (Badan Pusat Statistik Provinsi Papua, 2017).

Direktur Jenderal Pendidikan Anak Usia Dini dan Pendidikan Masyarakat (Dirjen PAUD dan Dikmas), Harris lskandar (dalam Harian Suara.com, 2018) mengatakan bahwa diantara 34 provinsi di Indonesia, terdapat 11 provinsi diantaranya memiliki angka buta huruf di atas angka nasional, yaitu Papua $(28,75 \%)$, NTB $(7,91 \%)$, NTT $(5,15 \%)$, Sulawesi Barat $(4,58 \%)$, Kalimantan Barat
(4,50\%), Sulawesi Selatan (4,49\%), Bali $(3,57 \%)$, Jawa Timur $(3,47 \%)$, Kalimantan Utara $(2,90 \%)$, Sulawesi Tenggara $(2,74 \%)$, dan Jawa Tengah $(2,20 \%)$.

Penyebab tingginya angka buta aksara di provinsi Papua dikarenakan lokasi yang sulit dijangkau, sarana transportasi yang sangat terbatas, jarak pemukiman yang saling berjauhan, minimnya tenaga pendidik, terbatasnya layanan pendidikan seperti sekolah, dan mata pencaharian masyarakat yang bervariasi seperti penebang pohon atau pencari kayu bakar, petani, dan pencari ikan.

Tingginya angka buta aksara di Papua khususnya di Kabupaten Jayawijaya mendorong berbagai praktisi pendidikan untuk mengatasi masalah tersebut salah satunya adalah Sekolah Tinggi Keguruan dan Ilmu Pendidikan Kristen Wamena untuk melakukan program pendampingan terhadap warga masyarakat Wamena yang berusia 15 tahun ke atas dalam pengentasan buta aksara di Wamena. Khususnya di Distrik Walelagama Kampung Walelagama.

\section{KAJIAN LITERATUR Keaksaraan}

Keaksaraan adalah kemampuan seseorang dalam membaca, menulis, dan berhitung (EFA Global Report, 2005). Pengertian ini menjelaskan bahwa seseorang yang mengalami pendidikan keaksaraan akan memiliki kemampuan literasi yang baik yang dikatakan melek huruf. Sedangkan ketidakmampuan seseorang untuk membaca atau menulis kata-kata atau kalimat sederhana dalam aksara apapun disebut buta huruf/aksara (Badan Pusat Statistik Provinsi Papua, 2017). Buta aksara adalah kelompok masyarakat usia lanjut yang tidak mendapatkan pendidikan sekolah dikarenakan ketidakmampuan dalam ekonomi. Buta aksara fungsional merupakan ketidakmampuan seseorang memanfaatkan kemampuan membaca, menulis, dan berhitung dalam kehidupan sehari-hari (Direktorat Pendidikan Masyarakat, Dirjen Pendidikan Luar Sekolah, Departemen Pendidikan Nasional, 2006). 
Dengan demikian dapat disimpulkan bahwa buta aksara adalah masyarakat pada usia tertentu yang tidak memiliki kemampuan dalam mebaca atau menulis huruf atau kalimat dalam bahasa apapun.

\section{Faktor-Faktor Penyebab Buta Aksara}

Beberapa faktor yang menyebabkan seseorang buta aksara sebagai berikut (Wibowo, 2015):

1) Tidak pernah sekolah atau putus sekolah karena faktor budaya, ekonomi, sosial (Mariyono, 2016), politik, dan gender.

2) Kemiskinan.

3) Jarak layanan pendidikan yang jauh dari tempat tinggal.

\section{Upaya Mengentas Buta Aksara}

Syamsiah (2015) mengungkapkan beberapa cara mengentas buta aksara sebagai berikut:

1) Mengurangi jumlah anak yang tidak bersekolah.

2) Inovasi metode pembelajaran.

3) Keseriusan pemerintah dalam mengatasi anak tidak bersekolah atau putus sekolah.

4) Keterlibatan berbagai pihak dalam upaya percepatan pemberatasan buta aksara.

Berdasarkan pengertian, penyebab, dan upaya pengentasan buta aksara di atas, maka dapat disimpulkan bahwa dalam mempercepat pemberantasan buta aksara di suatu daerah dibuthkan keterlibatan berbagai pihak, bukan hanya pemerintah namun semua unsur harus terlibat untuk mengatasi buta aksara tersebut melalui program-program tertentu yang sesuai dengan kapasitas masing-masing.

\section{METODE PELAKSANAAN}

\section{Waktu dan Tempat Pelaksanaan}

Program pendampingan percepatan pemberantasan buta aksara dilaksanakan selama 3 bulan ddari bulan maret 2018 - mei 2018. Program ini dilaksanakan di Distrik Walelagama kampung Walelagama,
Wamena, Kabupaten Jayawijaya, Provinsi Papua.

\section{Sasaran}

Program pendampingan ini ditunjukan bagi masyarakat Walelagama yang berusia 15 tahun sampai dengan usia 45 tahun. Baik bagi mereka yang tidak pernah sekolah maupun yang putus sekolah.

\section{Tutor dan Pendamping}

Tutor dalam pelaksanaan program pendampingan keaksaraan terdiri dari 2 orang mahasiswa yang telah dilatih dan 1 orang dosen sebagai pendamping tutor.

\section{Prosedur Pelaksanaan}

Pelaksanaan program pendampingan keakasaraan dilaksanakan melalui beberapa tahap sebagai berikut:

1. Observasi lokasi/tempat pelaksanaan.

2. Melakukan tes awal pada masyarakat yag kemudian disebut sebagai warga belajar (WB) untuk mengetahui kemampuan masyarakat dalam mengenal huruf dan angka.

3. Persiapan modul keaksaraan yang diambil dari Buku Pelajaran Kontekstual Papua (BPKP) yang dibuat dan diproduksi sendiri oleh Yayasan Kristen Wamena (YKW). Buku ini telah dipergunakan dalam pelajaran Matematika dan Bahasa Indonesia kelas 1 - 3 di beberapa sekolah dasar (SD) di Pegunungan Tengah Papua.

4. Pelaksanaan pendampingan dengan menggunakan metode yang menyenangkan dan sederhana (Fun and Simple Learning).

5. Tes akhir bertujuan untuk mengetahui tingkat kemampuan warga belajar setelah menjalani program pendampingan.

\section{HASIL PEMBAHASAN}

Distrik Walelagama merupakan salah satu distrik di Kabupaten Jayawijaya yang terletak di daerah lembah. Distrik Walelagama berada pada ketinggian 1645 - 1890 meter dpl, 
sehingga wilayahnya sebagian besar berupa lereng. Distrik Walelagama terdiri dari 7 kampung yaitu; Pugima, Walelagama, Kulaken, Wamusage, Itlay Halitopo, Kubulakma.

Jumlah penduduk di Distrik Walelagama sebanyak 1864 jiwa yang terdiri dari 906 laki-laki dan 985 perempuan. Penduduk terbanyak terdapat pada Kampung Walelagama yaitu sebesar 988 jiwa atau sebesar $53 \%$ dari total penduduk di Distrik Walelagama. Jumlah sekolah yang ada di kampung Walelagama sebanyak 2 yang terdiri dari 1 Sekolah Dasar Swasta (SDS) dan 1 Sekolah Menengah Pertama Negeri (SMPN) (Badan Pusat Statistik Kabupaten Jayawijaya, 2016).

Berdasarkan data di atas menunjukkan bahwa jumlah penduduk di kampung Walelagama tidak sebanding dengan jumlah sekolah yang ada sehingga diperkirakan banyak masyarakat (warga) kampung Walelagama tidak mendapatkan pendidikan yang semestinya ataupun banyak warga yang putus sekolah baik disebabkan karena faktor motivasi, budaya, ekonomi, dan pelayanan pendidikan yang hanya sampai pada tingkat SMP di kampung Walelagama.

Untuk itu, sebagai institusi yang peduli terhadap mutu pendidikan di Pegunungan Tengah Papua, Sekolah Tinggi Keguruan dan Ilmu Pendidikan Kristen Wamena merasa bertanggung jawab untuk memperbaiki taraf hidup masyarakat Papua melalui program penuntasan buta aksara bagi masyarakat kampung Walelagama yang berusia 15 tahun ke atas baik laki-laki maupun perempuan, baik yang tidak pernah sekolah maupun yang putus sekolah yang belum bisa membaca, menulis, dan berhitung (CALISTUNG).

Program pendampingan keaksaraan diawali dengan melakukan observasi lokasi yang akan dijadikan pos belajar serta permintaan ijin untuk pelaksanaan program melaui pengajuan surat ke tokoh masyarakat yang mempunyai pengaruh di kampung Walelagama yaitu ke Gereja Kemah Injili di Tanah Papua Jemaat Muria.

Kerjasama dengan pihak gereja memudahkan dalam koordinasi masyarakat di kampung Walelagama dikarenakan sebagian besar masyarakat kampung Walelagama merupakan jemaat di gereja tersebut.

Setelah mendapatkan surat ijin pelaksanaan program, maka pihak STKIP Kristen Wamena melalui penugasan salah satu Dosen sebagai pendamping dan 2 orang mahasiswa sebagai tutor untuk melakukan tes awal. Tujuan dilakukan tes awal adalah untuk mengetahui kemampuan mengenal huruf dan angka pada calon warga belajar.

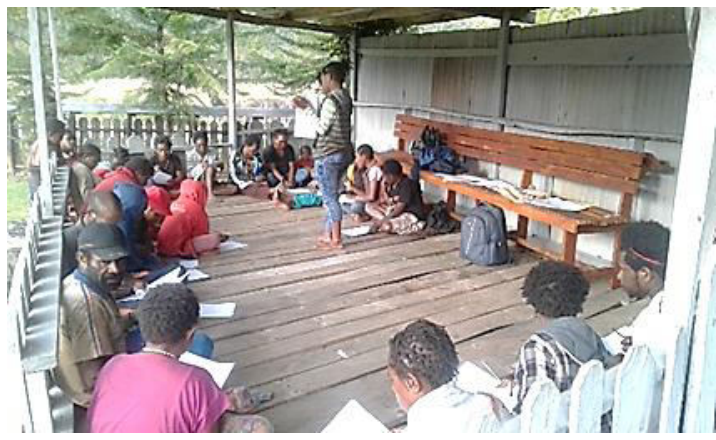

Gambar 1. Tes Awal Kemampuan Membaca dan Berhitung Warga Belajar Kampung Walelagama.

Hasil tes awal mengenal huruf latin dan membaca serta menulis (CALIS) dapat dilihat pada grafik berikut:

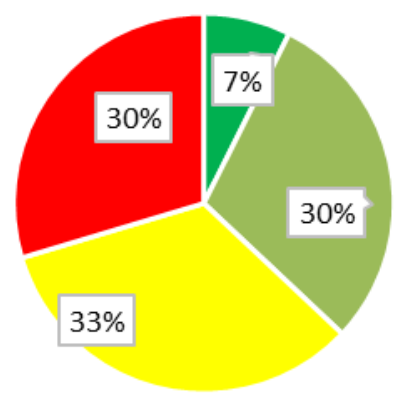

Nilai

- $80-100=60-79=40-59=20-39=0-19$

Gambar 2. Hasil Tes Awal Calis

Berdasarkan grafik di atas dapat diketahui bahwa hampir seluruh warga belajar memiliki kemampuan baca tulis yang sangat kurang yaitu sekitar 30\%, kemampuan kurang sebanyak 33\% dan kemampuan cukup 
sebanyak $30 \%$ sedangkan sisanya $7 \%$ memiliki kemampuan baca tulis yang baik.

Namun demikian dari seluruh warga belajar yang telah di tes awal akan diberikan pendampingan keaksaraan khususnya dalam membaca kata-kata dalam huruf latin. Sebelum dilakukan pendampingan makan persiapan yang dilakukan adalah membuat modul baca, tulis, dan hitung. Baik dalam pengenalan huruf dan membaca kata serta mengenal angka dan perhitungan sederhana. Namun progam pendampingan difokuskan pada pendampingan Baca dan Tulis huruf dan kata. Hal ini dikarenakan dari hasil tes awal pengenalan angka dan perhitungan sederhana menunjukkan hasil yang lebih baik, seperti pada grafik berikut:

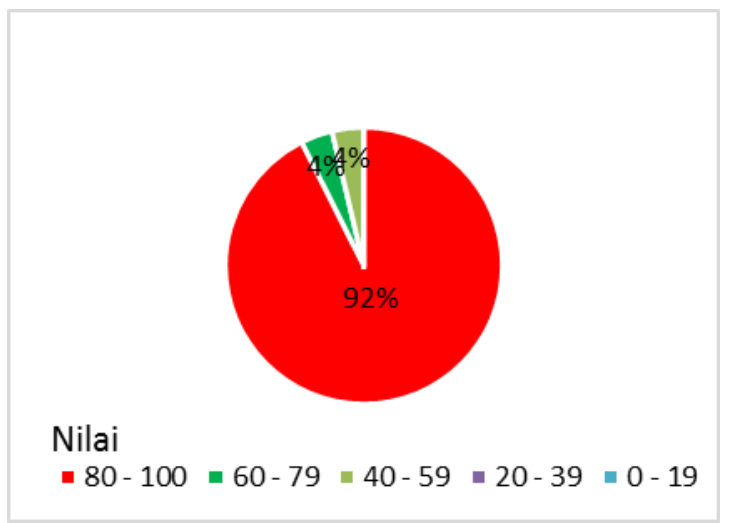

Gambar 3. Hasil Tes Awal Hitung

Program pendampingan keaksaraan dimulai pada pengenalan huruf sampai pada membaca kata. Program ini dilakukan selama 3 bulan yang didampingi oleh 2 orang mahasiswa sebagai tutor dan 1 orang dosen sebagai pembina. Teknik-teknik yang digunakan dalam pelaksanaan pendampingan keaksaran merupakan kombinasi pembelajaran yang menyenangkan melalui permainan dan pembelajaran yang sederhana melalui pemberian kata-kata yang sehari-hari digunakan baik dalam bahasa Indonesia maupun bahasa daerah (Bahasa Dani).

\section{Pengenalan Huruf}

Beberapa pendekatan yang digunakan dalam pengenalan huruf pada warga belajar antara lain: penggunaan bunyi benda, mewarnai huruf, dan menggambar huruf melalui garis putus-putus yang telah disediakan pada modul yang diberikan, serta pengenalan huruf dengan menggunakan media Flash Card.

\section{Pengenalan Huruf Melalui Bunyi dan Media Visual}

Pengenalan huruf dengan menggunakan nama-nama benda yang dijumpai dalam kehidupan sehari-hari akan membantu anakanak dalam mengenal huruf misalnya kata "Sike" dalam bahasa Dani (Indonesia = Panah) yang diawali dengan huruf "S". Hal ini didasarkan pada ketertarikan seseorang pada nama-nama benda yang mudah mereka kenali. Selain itu, pengenalan huruf juga dilakukan melalui nama warga belajar, karena ketertarikan warga belajar ketika mereka dapat menuliskan nama mereka sendiri dan menyebutkan hurufnya serta mengejanya. Oleh karena itu, materi menulis dan membaca sebaiknya dimulai dari minat/ketertarikan dan kebutuhan warga belajar, bukan dari teks-teks yang tidak mereka kenali.

Sebagai seorang tutor/pengajar dapat memulai interaksi tentang hewan peliharaan seperti Babi, dan dijelaskan secara rinci dalam bagian kata Babi yaitu "Kata Babi diawali dengan huruf B". Seseorang akan lebih mudah memahami jika kata benda tersebut disertai dengan gambar (visual), sehingga huruf-huruf yang diperkenalkan kepada warga belajar merupakan bahan untuk mengindentifikasi secara visual bukan hanya ingatan saja.

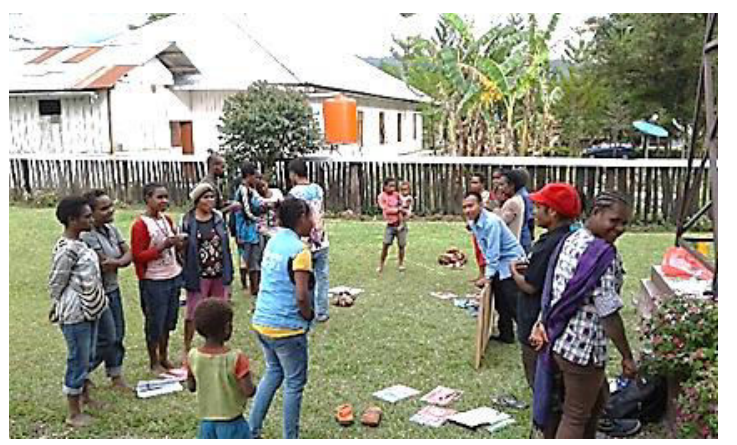

Gambar 4. Permainan Pengenalan Huruf Melalui Bunyi Benda 


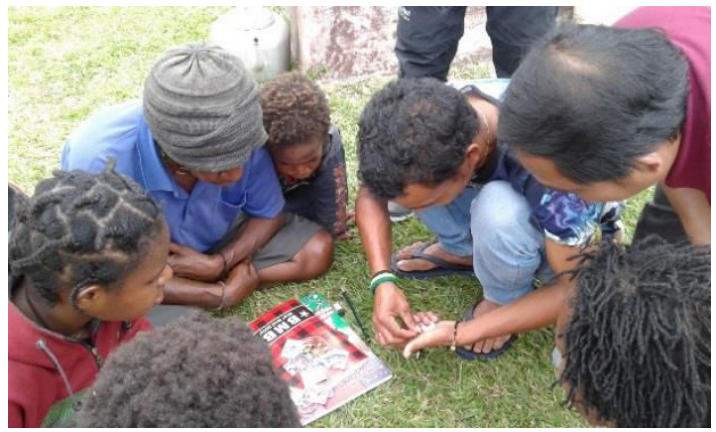

Gambar 5. Permainan Pengenalan Huruf Melalui Media Visual

\section{Pengenalan Huruf Melalui Goresan/Menggambar}

Selain mengenal huruf lewat bunyi dan media visual, juga digunakan pendekatan melalui goresan menggambar huruf (menyatukan garis putus-putus). Pendekatan ini bertujuan untuk melatih motorik warga belajar sehingga terbiasa dalam menggambar huruf sesuai dengan tema tertentu. Tujuan akhir dari pengenalan huruf melalui pendekatan ini adalah untuk melatih warga belajar dalam menulis.

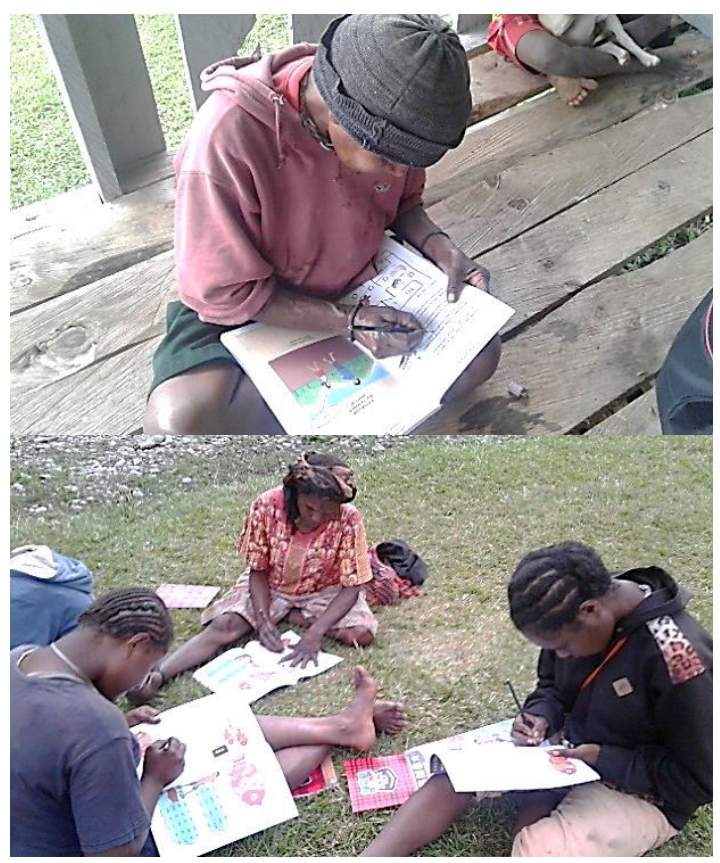

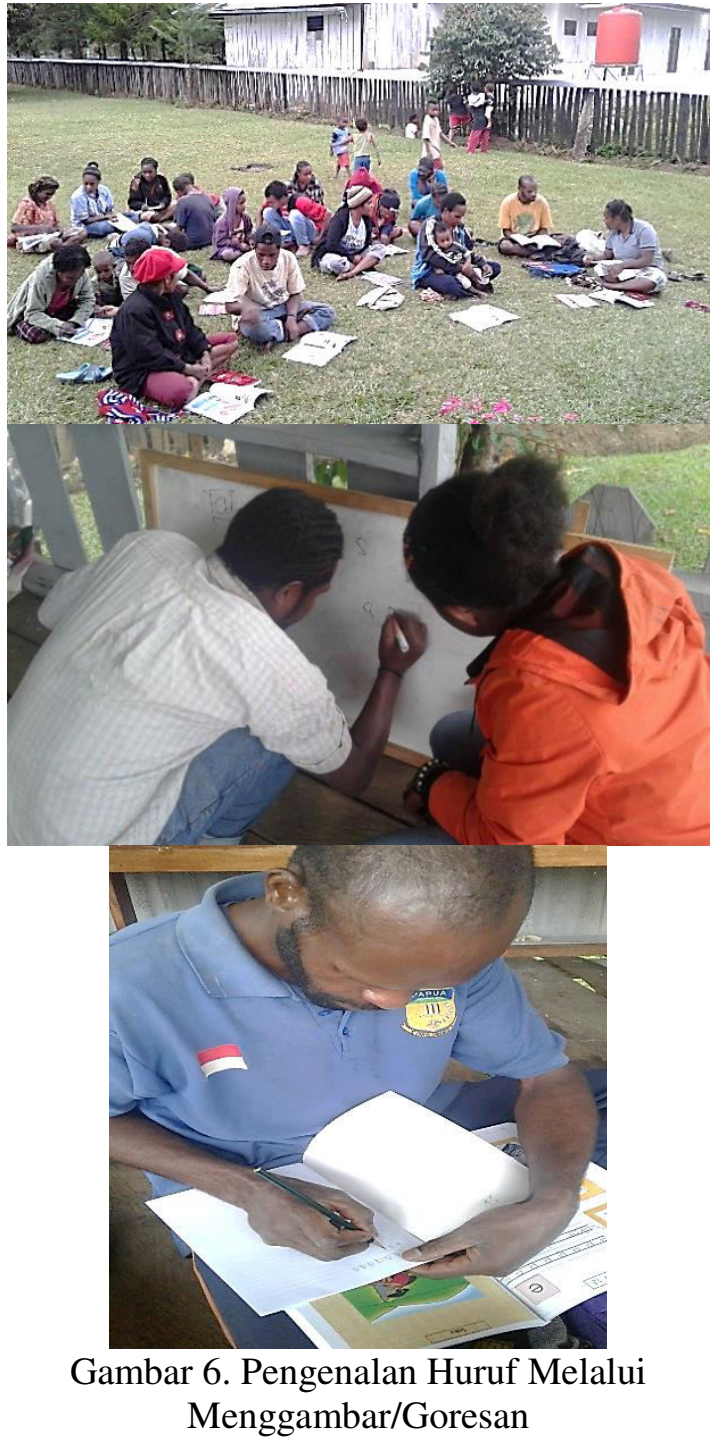

\section{Pengenalan Huruf Melalui Media Flash Card}

Pendekatan yang ketiga ini digunakan setelah warga belajar melewati pendekatan pengenalan huruf melalui bunyi, media visual, dan menggambar/goresan. Tujuan penggunaan flash card adalah untuk melatih ingatan warga belajar tentang huruf-huruf yang telah dipelajari sebelumnya sehingga selain melatih motorik warga belajar juga melatih kognitifnya. 


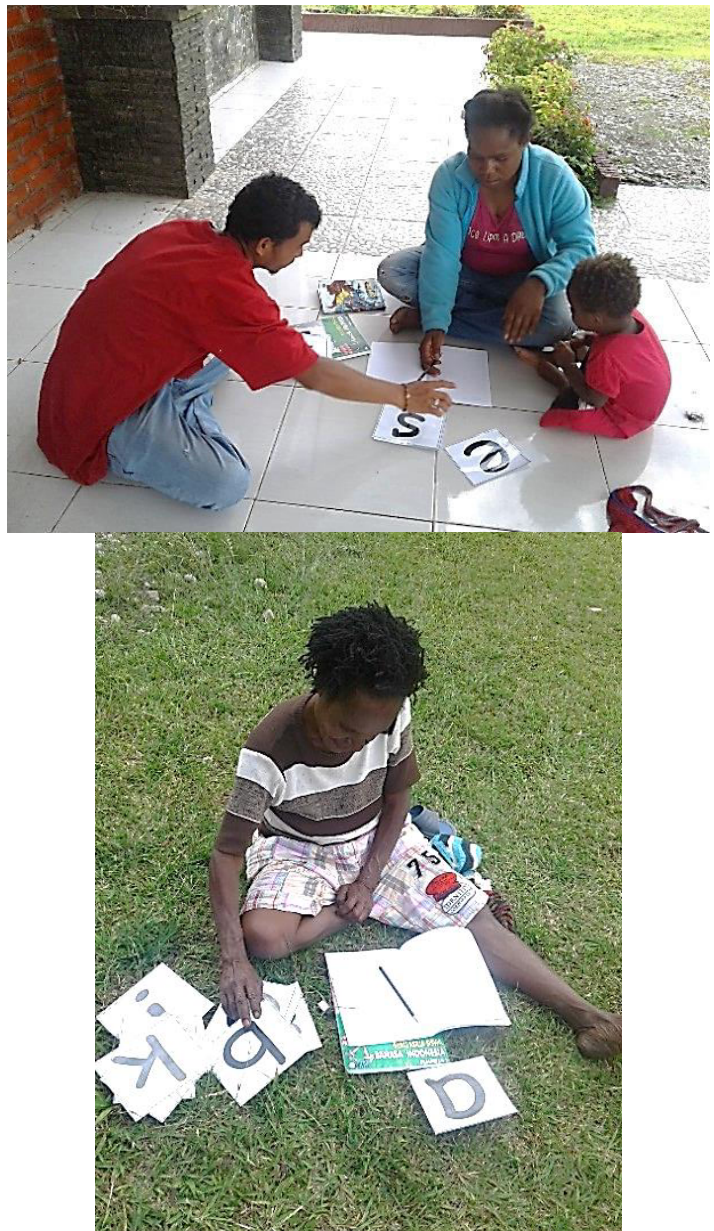

Gambar 7. Pengenalan Huruf Melalui Media Flash Card

\section{Membaca dan Mengeja Kata}

Pendekatan yang digunakan dalam pendampingan membaca dan mengeja sebagai dasar dari kemampuan literasi seseorang yaitu pendekatan dengan menggunakan media Flash Card dan media Visual. Melalui pendekatan ini, warga belajar mengalami peningkatan kemampuan dalam mengeja dan membuat suku kata setelah program pendampingan dilaksanakan selama 2 bulan.

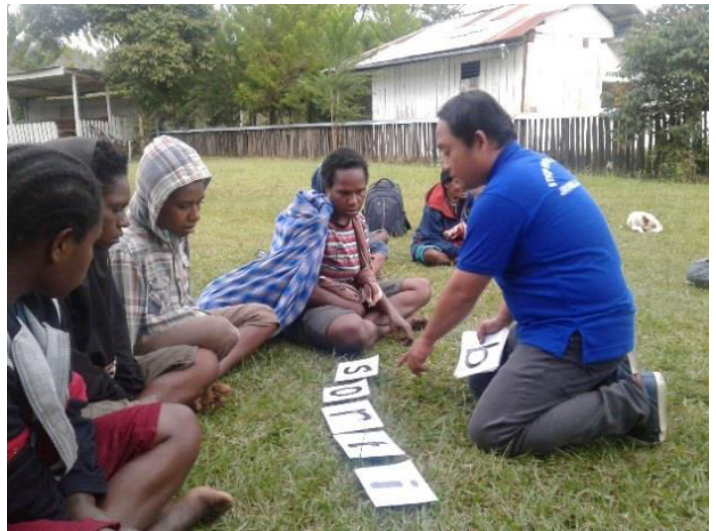

Gambar 8. Membaca Kata

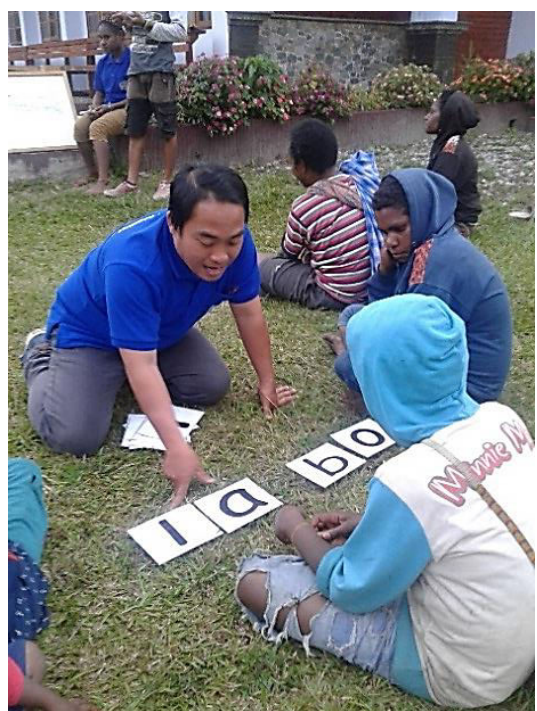

Gambar 9. Mengeja Suku Kata

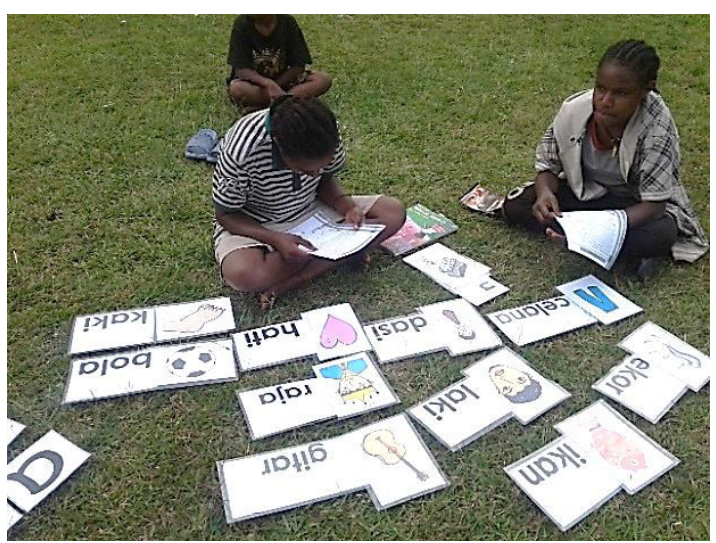




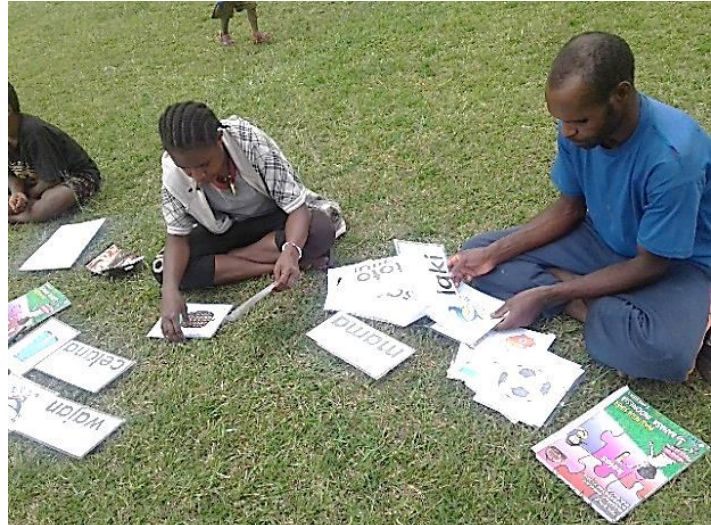

Gambar 10. Membaca Melalui Media Visual

Setelah dilakukan pendampingan selama 3 bulan, maka langkah terakhir adalah dilakukan tes akhir untuk mengukur keberhasilan program pendampingan tersebut. Hasil tes akhir baca dan tulis (CALIS) dapat dilihat pada grafik berikut:

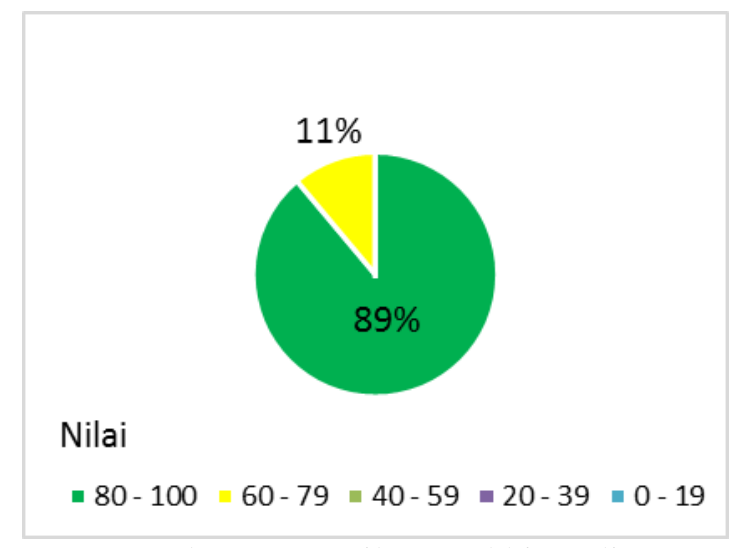

Gambar 11. Hasil Tes Akhir Calis

Berdasarkan grafik di atas menunjukkan bahwa kemampuan membaca dan menulis warga belajar mengalami peningkatan setelah diberikan pendampingan selama 3 bulan. Sebanyak 89\% warga belajar memiliki kemampuan baca tulis yang sangat baik dan sebanyak $11 \%$ dalam kategori baik. Persentase ini jauh lebih baik jika dibandingkan dengan persentase pada hasil tes awal sebelum dilakukan pendampingan keaksaraan.

\section{KESIMPULAN}

Program pendampingan keaksaraan yang dilaksanakan selama 3 bulan berdampak positif terhadap kemampuan membaca dan menulis warga belajar yang ada di kampung Walelagama. Sebanyak $89 \%$ warga belajar memaliki kemampuan baca tulis yang sangat baik sedangkan sisanya $11 \%$ berkategori baik. Pendekatan yang digunakan sebaiknya disesuaikan dengan kebutuhan warga belajar, misalnya pada warga belajar di kampung Walelagama pendekatan yang digunakan adalah Fun and Simple Learning antara lain; penggunaan bunyi benda, mewarnai huruf, menggambar huruf melalui garis putusputus, dan menggunakan media flash card, serta membaca dan mengeja dengan bantuan media flash card dan gambar/visual.

\section{REFERENSI}

Badan Pusat Statistik Provinsi Papua. 2017. Indikator Pendidikan Provinsi Papua, Katalog: 4302002.94.

Badan Pusat Statistik Kabupaten Jayawijaya. 2016. Kecamatan Walelagama Dalam Angka, Katalog: 1102001.9402112.

Direktorat Pendidikan Masyarakat, Dirjen Pendidikan Luar Sekolah, Departemen Pendidikan Nasional. 2006. Pedoman Pelaksanaan : Gerakan Nasional Percepatan Penuntasan Wajib Belajar Pendidikan Dasar Sembilan Tahun dan Pemberantasan Buta Aksara, Jakarta.

EFA Global Monitoring Report. (2005). Education For All (Literacy for Life). Perancis: UNESCO.

Mariyono. 2016. Strategi Pemberantasan Buta Aksara Melalui Penggunaan Teknik Metastasis Berbasis Keluarga, Jurnal Pancaran Vol. 5 No. 1, hal 5566 Februari 2016.

Harian Jaringan Kerja Rakyat (JERAT) Papua. 2015. Tinggi Buta Aksara, PR Besar Pemerintah, Publikasi pada 21 Maret 2015. http://www.jeratpapua.org/2015/03/21/ tinggi-buta-aksara-pr-besarpemerintah/

Harian Suara.com. 2018. Tigkat Buta Aksara Di Indonesia Turun Drastis, publikasi pada Selasa 04 September 2018: 14.05 WIB.

https://www.suara.com/health/2018/09 
/04/140511/kemendikbud-tingkat-butaaksara-di-indonesia-turun-drastis

Syamsiah. 2015. Pemberdayaan Masyarakat Desa yang Buta Huruf. Jurnal Equilibium Pendidikan Sosiologi, 3 (2).

Undang-Undang Dasar Negara Republik Indonesia Tahun 1945. Amandemen IV.

Wibowo, Puguh Langgeng. 2015. Efektifitas Program Education For All Oleh Unesco dalam Penanggulangan Buta Huruf di Indonesia. eJournal Ilmu Hubungan Internasional, 3 (2): 277286. 
VOL. 03. NO. 1, JANUARI 2019 